\title{
Ameliyathanede çalışan hekim ve hemşirelerin iletişimde yaşadıkları sorunlar ve öfke ifade tarzlarının belirlenmesi
}

Nevin ONAN ${ }^{1}$, Iş11 IŞIK ANDSOY ${ }^{2}$ Rabia GÖRÜCÜ ${ }^{3}$

\begin{abstract}
$\ddot{\mathbf{O z}}$
İletişim ve işbirliği ameliyathane gibi karmașık hizmet alanlarında hayati önem taşımaktadır. Araştırma, ameliyathanede çalışan hekim ve hemşirelerin iletişimde yaşadıkları sorunlar ve öfke ifade tarzlarının belirlenmesi amacıyla gerçekleștirildi. Araștırma; Haziran-Temmuz 2017 tarihleri arasında Karabük ilinde bir eğitim- araştırma ve bir ilçe devlet hastanesinin ameliyathanelerinde çalışan ve çalışmaya katılmayı kabul eden 30 hekim ve 26 hemşire ile gerçekleştirildi. Veriler Katılımcı Bilgi formu ve Sürekli Öfke ve Öfke İfade Tarzı Ölçeği (SÖÖTÖ) ile toplandı, tanımlayıcı istatistikler, Mann Whitney U testi ve spearmen korelasyon analizi kullanılarak değerlendirildi. Katılımcıların \%60,7'si ekiple iletișimlerini olumlu değerlendirdiklerini belirtti. Her iki grup ekiple iletişim sorununu ameliyathanede en az karşılaşılan sorunlar arasında belirtti. Görev ve sınırlılıkların bilinmemesi, tanınmama, motivasyon düşüklüğü, hekimlerin amir gibi davranması, yeterli sayıda tıbbi malzemenin ve personelin bulunmamasının iletişimde her zaman güçlük yarattığı çalışmaya katılan hemşireler tarafından belirtildi. İletişim güçlüğü yaşandığında sorunu ortadan kaldırmak için katılımcıların çoğunluğunun çözüm yolu arama ve karşılıklı konuşma davranışını seçtiği belirlendi. Hemşirelerin ve hekimlerin sürekli öfke puan ortalamaları sırasıyla 18,5 $\pm 5,0$,

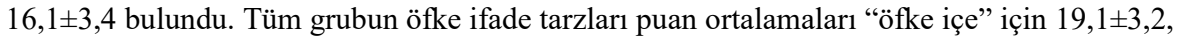

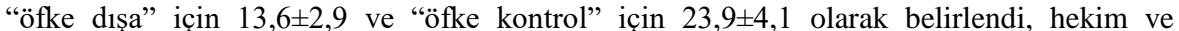
hemşireler arasında öfke tarzları açısından anlamlı bir fark saptanmadı. Hekim ve hemşirelerin iletişim sorunlarına neden olan faktörleri farklı değerlendirdikleri, iletişim sorunlarına çözüm odaklı yaklaştıkları ve öfkelerini kontrol edebildikleri belirlenmiştir.
\end{abstract} Yayın Bilgisi

Anahtar Kelimeler: Ameliyathane, hekim, hemşire, iletişim, öfke

\section{Determination of the communication problems of physicians and nurses working in the operating room and of their anger expression styles}

Nevin ONAN ${ }^{1}$, Ișı1 IŞIK ANDSOY2, Rabia GÖRÜCÜ ${ }^{3}$

\begin{abstract}
Communication, collaboration and effective care are vital in complex service areas, especially in the operating room. The research was conducted in order to determine the communication problems and anger expression styles of physicians and nurses working in the operating room. It conducted between June and July 2017 with 30 physicians and 26 nurses who agreed to participate to study and who worked in the operation room of an education-research hospital and of a district state hospital in Karabük province. Data were collected using the Participant Information Form and the Trait Anger and Anger Expression Scale (TA-AES), using descriptive statistics, Mann Whitney $U$ and spearmen correlation analysis. 60,7\% of participants evaluated their communication positively. Both groups stated that the problem of communication was the least common problem in the operating room. The nurses, whose duty and limitations were unknown, low motivation, physicians acting as supervisors, and the lack of adequate medical supplies and personnel, always made communication difficult. Mean anger score of nurses and physicians were $18,5 \pm 5,0,16,1 \pm 3,4$ respectively. The men score of

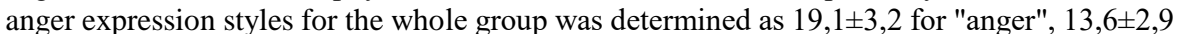
for "anger out" and 23,9 $\pm 4,1$ for "anger control", while among physicians and nurses there was no significant difference detected in terms of anger styles. Physicians and nurses can differentiate the factors that cause communication problems, can focus on solutions to communication problems and control their anger.
\end{abstract}

Article Info

Keywords: Operating room, physicians, nurses, communication, anger

${ }^{1}$ Karabük Üniversitesi, Sağl1k Bilimleri Fakültesi, Hemşirelik Bölümü, Psikiyatri Hemşireliği AD., Karabük

${ }^{2}$ Karabük Üniversitesi, Sağlık Bilimleri Fakültesi, Hemşirelik Bölümü, Karabük

${ }^{3}$ İstanbul Üniversitesi Cerrahpaşa Florence Nightingale Hemşirelik Fakültesi,İstanbul 


\section{GíRiș}

Sağlık ekibi, sağlık kurumlarında deneyimlerini sürekli paylaşan, ortak kararlara uyum sağlayan, bu kararları ekip ruhu içerisinde uygulayabilen ve hedefleri hastaya kaliteli sağlık bakımı veren çalışanlardan oluşmaktadır. ${ }^{1,2}$ Ekip üyeleri arasındaki sağlıklı ve etkili iletişim ekibin uyumunu ve başarısını etkilemektedir. ${ }^{3,4}$

Sağlık ekibinin içerisinde önemli bir yeri olan hekim ve hemşirelerin ekip anlayışıyla çalışacağı hastane içerisinde en önemli alanlardan birisi ameliyathanelerdir. İletişim ve işbirliği özellikle ameliyathane gibi karmaşık hizmet alanlarında hayati önem taşımaktadır. ${ }^{5,6}$ Bir ameliyathanede işlerin düzenli yürüyebilmesi için cerrahi ekip üyelerinin diğer klinik ve ilgili servisler arasında açık bir iletişimin ve iş birliğinin olması önemlidir. ${ }^{7,8}$

Ekip çalışmasıyla ilgili tutarsızlıklar stres ve memnuniyetsizlik nedeni olmaktadır. ${ }^{3,4,9}$ Diğer yandan ameliyathanede hataların oluşumuna en fazla neden olan ve hasta güvenliğini tehdit eden durumun ekip üyeleri arasındaki iletişim eksikliği olarak rapor edilmiştir. ${ }^{8-11}$ Ameliyathanede güvenlik kültürünün arttırılmasını sağlamak amacıyla geliştirilen süreçlerin odak noktası, ekip üyeleri arasında iletişimi arttırmaktır. ${ }^{7-10,12}$ Ameliyathanelerde güvenlik kültürünün oluşturulmasında ve hasta güvenliğinin sağlanmasında, hataların en aza indirilmesinde, çatışmaların çözümünde, etkin bir ekip çalışmasının oluşturulmasında, iş doyumunun sağlanmasında, iş stresinin azaltılmasında, personelin karar verme sürecini geliştirmede, üretkenliğin arttırılmasında vazgeçilmez olan durumun etkili iletişim olduğu literatürde belirtilmektedir. ${ }^{12-16}$

Ameliyathanelerde özellikle sözsüz iletișim sıklıkla kullanılmakta ve dolayısıyla bu durum farklı algilamalara neden olabilmektedir. Cerrahın çok fazla sessiz kalması, sinirli ve sesini yükseltmesi gibi durumlar diğer ekip üyeleri arasında kızgınlık, suçluluk, belirsizlik, kaygı, yok sayılma gibi etkiler yaratabilmektedir. Aynı zamanda kullanılan mesleki dilin ortak ve standartlaştırılmış bir dil olmaması, gürültülü ortam gibi diğer birçok etken ameliyathane ortamlarında iletişim sorunlarına ve strese yol açmaktadır. ${ }^{8,14,17} \mathrm{Bu}$ durum, yoğun çalışma temposu sonucu oluşan stres ve tükenmişlik ile kișilerin birbirlerine öfke patlamaları gibi gergin ve yıkıcı davranışlarda bulunmasına neden olabilmektedir. Öfke ve öfkenin ifade biçimi, kişilerarası ilişsilerde, ekip içi iletişimde, fiziksel, ruhsal ve sosyal sorunlar yaşanmasında önemli bir rol oynamaktadır. Öfkenin kontrol edilerek, doğru ifade edilmesi iletişim problemlerini azaltmakta, iş performansı ve iş doyumunu arttırmakta, ${ }^{18}$ sağlik hizmetlerinin kalitesini yükseltmektedir. ${ }^{19}$

Konuyla ilgili yapılan çalışmalarda, hasta ve çalışan güvenliğinin sağlanmasına yönelik başlıca engellerden biri olarak hekim-hemşire arasında yaşanan iletişim sorunlarının gösterildiği bulunmuştur. ${ }^{15,16,20}$ Hekimlerle hemşireler arasında etkin ve sağlıklı bir iletişim 
sisteminin kurulması ve iletişim kanallarının arttır1mas1 önem kazanmaktadır. $^{2}$ Hemşire/hekim iletişiminin ekip çalışması ve güvenliği konusundaki önemli rolünü anlamak için iletişimle ilgili araştırmalara ihtiyaç duyulmaktadır. $\quad 2-4,7,20 \quad \mathrm{Bu}$ bilgiler 1 şı̆̆ında ameliyathanelerde var olan ve olası sorunların çözümünde hekim ve hemşireler arasında yaşanan iletişim davranışlarının ve sorunlarının belirlenmesi ilk ve en önemli adım olarak düşünülmüştür. Ayrıca ameliyathanelerde hekim ve hemşirelerin iletişim ve öfke ifade biçimini değerlendiren sınırlı sayıda çalışmaya rastlanmıştır. $^{11} \mathrm{Bu}$ çalışma ameliyathanede çalışan hekim ve hemşirelerin iletişimde yaşadıkları sorunlar ve öfke ifade tarzlarının belirlenmesi amacıyla gerçekleştirilmiştir.

\section{MATERYAL ve METOT}

Araștırma, ameliyathanede çalışan hekim ve hemşirelerin iletişimde yaşadıkları sorunlar ve öfke ifade tarzlarının belirlenmesi amacıyla hekim ve hemşirelerin görüşlerini değerlendiren tarama modelinde tanımlayıcı bir araştırmadır.

\section{Araştırmanın evren ve örneklemi}

Araştırmanın evrenini, Karabük ilinde bulunan bir eğitim araştırma hastanesi ve bir ilçe devlet hastanesinin ameliyathanesinde çalışan 90 hemşire ve hekim oluşturdu. Araştırma, verilerin toplandığ 1 tarihlerde (Haziran-Temmuz 2017) izinde olmayan ve çalışmaya katılmaya gönüllü olan 26 hemşire ve 30 hekimle gerçekleştirildi.

\section{Verilerin toplanmast}

Araştırma verileri; çalışmaya katılan hekim ve hemşirelerle yüz yüze görüşülerek Katılımc1 Bilgi Formu ve Sürekli Öfke ve Öfke İfade Tarzı Ölçeği (SÖ-ÖTÖ) kullanılarak toplandı.

\section{Veri toplama araçları}

Çalışmada kullanılan katılımcı bilgi formu yaş, cinsiyet, mezun olunan okul, çalışma süresi, çalışma ortamından memnuniyet durumu, hekim hemşire iletişimi ve yaşanan sorunlar, nedenleri ve tepkileri belirlemeyi amaçlayan 42 sorudan oluştu.

Sürekli Öfke ve Öfke İfade Tarzı Ölçeği (SÖÖTÖ): Öfke duygusu ve ifadesini ölçen kendini değerlendirme ölçeğidir. Spielberger tarafından 1983 y1lında geliştirilmiş, Türkçe uyarlaması, geçerlik ve güvenilirliği Özer (1994) tarafından yapılmıştır. $^{21}$ Ölçek, içe yönelik öfke, dışa yönelik öfke, öfke kontrol ve sürekli öfke olmak üzere dört alt ölçekten ve 34 maddeden oluşmaktadır. Ölçeğin değerlendirilmesinde "Hiç tanımlamıyor" yanıtına 1 puan, "Biraz tanımlıyor" yanıtına 2 puan, “Oldukça tanımlıyor” yanıtına 3 puan, “Tümüyle tanımlıyor" yanıtına 4 puan verilir. Ölçeğin genel toplam puanı olmayıp, dört alt ölçeğin maddeleri o alt ölçeğin toplam puanını oluşturmaktadır. İçe yönelik öfke, dışa yönelik öfke ve öfke kontrol alt ölçeklerinden alınabilecek en düşük puan 8 , en yüksek puan 32; sürekli öfke alt ölçeğinden alınabilecek en düşük puan 10, en yüksek puan 40’tır. Sürekli öfke alt ölçeğinden alınan yüksek 
puanlar öfke düzeyinin yüksek olduğunu, öfke kontrol alt ölçeğinden alınan yüksek puanlar öfkenin kontrol edilebildiğini, dışa yönelik öfke alt ölçeğinden alınan yüksek puanlar öfkenin kolayca ifade edildiğini, içe yönelik öfke alt ölçeğinden alınan yüksek puanlar ise öfkenin bastırılmış olduğunu gösterir. Orjinal ölçeğin cronbach $\alpha$ değerleri ‘öfke kontrolü’ boyutu için 0,84; 'öfke dişa vurumu' boyutu için 0,78 ve 'öfke içe vurumu' boyutu için 0,62 olarak bulunmuştur. $^{21,22}$ Çalışma için cronbach $\alpha$ değerleri, sürekli öfke boyutu için 0,75 , öfke içte alt boyutu için 0,70 , öfke dişta alt boyutu için 0,73 ve öfke kontrol alt boyutu için 0,75 olarak belirlendi.

\section{Verilerin değerlendirilmesi}

Araştırma kapsamında elde edilen veriler bilgisayar ortamında değerlendirildi. Verilerin dağılımları incelenerek non parametrik olduğu belirlendi. Veriler tanımlayıcı istatistiksel analizler, bağımsız iki grubun karşılaştırılmasında non parametrik yöntem olarak Mann Whitney $U$ testi ve spearmen korelasyon analizi kullanılarak değerlendirildi.

\section{Araştırmanın etik yönü}

Veriler toplanmadan önce Karabük Üniversitesi Etik Kurul'undan (25/06/2015 tarih ve 2015/07 sayılı) etik onay ve çalışmanın yapılabilmesi için kurum izni alındı. Araştırmada katılımcılara çalışmanın içerik ve amacı açıklandı, çalışma gönüllülük esasına göre yürütüldü. Hekim ve hemşirelerden sözel onam alındı.

\section{Araş̧tırmanın sınırlılı̆̆ı}

Araştırma; yalnızca bir ilde bulunan üniversite ve ilçe devlet hastanesinin ameliyathanesinde görev yapan hekim ve hemşireler ile sınırlıdır.

\section{BULGULAR}

Çalışmada yer alan toplam 56 (30 hekim ve 26 hemşire) katılımcının \%53,6'sı erkek, \%87,5'i

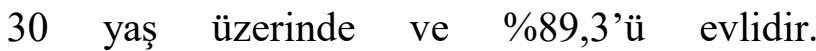
Katılımcıların meslekte çalışma süre ortalaması $15,3 \pm 1,1$ olup, \%50'sinin mesleğini değiştirmek istediği belirlendi (Tablo 1).

Çalışmada katılımcıların ekipteki iletişim ile ilgili görüşleri Tablo 2'de yer aldı. Katılımcıların \%60,7'sinin ekiple iletișimlerini olumlu değerlendirdikleri görüldü. Ameliyat sırasında kendilerini en fazla öfkelendiren durumu hemşirelerin \%69,2'si steril saha dışındaki ameliyathane personelinin yetersizliği, hekimlerin \%50'si ise cerrahi el aletlerinin kalitesizliği olarak belirtti. Ameliyat sırasında hekimlerin öfkeli davranışlarına maruz kalma ve çok fazla olumsuz etkilenme oranı hemşirelerde \%38,5 iken, hemşirelerin öfkeli davranışlarına hekimlerin maruz kalmadıkları belirlendi. Her iki grup da ekiple iletişim sorununu ameliyathanede en az karşılaşılan sorunlar arasında belirtti. Görev ve sınırlılıkların bilinmemesi, tanınmama, motivasyon düşüklüğü, hekimlerin amir gibi davranmas1, yeterli say1da tıbbi malzemenin ve personelin bulunmamasının iletişimde her zaman güçlük yarattığı çalışmaya katılan hemşireler 
tarafindan ifade edildi. Ameliyat sirasında yetersizlik yaşayan bir ekip üyesi olduğunda katılımcılardan her iki grupta da yüksek oranda (hemşire \%73,1; hekim \%90) "normal ses tonu ile uyarırım" cevabı alındı ve iletişim güçlüğü yaşandığında da sorunu ortadan kaldırmak için katılımcıların çoğunluğunun çözüm yolu arama ve karşılıklı konuşma davranışını seçtiği belirlendi.

Tüm grubun öfke ifade tarzları puan ortalamaları

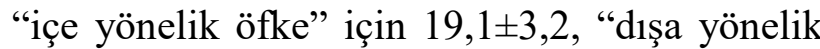
öfke" için 13,6 $\pm 2,9$ ve "öfke kontrol" için 23,9 $\pm 4,1$ olarak bulundu (Tablo 3).

Hekim ve hemşireler arasında öfke ifade tarzları açısından anlamlı bir fark saptanmadı $(\mathrm{p}>0,05)$. Sürekli öfke puanları değerlendirildiğinde hemşirelerin puan ortalamasının $(18,5 \pm 5,1)$ hekimlerin puan ortalamasindan $(16,1 \pm 3,4)$ yüksek olmasına rağmen istatistiksel olarak anlamlı olmadığı görüldü $(Z=-1,733$ ve $\mathrm{p}=0,083$ ). Cinsiyete göre sürekli öfke ve öfke ifade tarzlarının bir farklılık göstermediği saptand $1(\mathrm{p}>0,05)$ (Tablo 4).

Meslekte çalışma süresi ile sürekli öfke ve öfke ifade tarzları arasında anlamlı bir ilişki belirlenmedi ( $p>0,05)$ (Tablo 5).

\section{TARTIŞMA VE SONUÇ}

Hastanelerde ve ameliyathanelerde görülen tıbbi hataların en önemli nedeninin \%60-80 oranında etkisiz iletişim ve ekip çalışmasındaki yetersizlikten kaynaklandığı belirtilmektedir. Hekim ile hemşire arasında ortaya çıkan anlaşmazlıklar; iletişim yetersizliğine bağlı uygulama hatalarına yol açarak çalışan güvenliğini ve hasta güvenliğini tehlikeye sokmaktadır. ${ }^{7,8,14,17}$ Çalışmada katılımcıların \%60,7'sinin ekiple iletişimlerini olumlu değerlendirmeleri ve ekiple iletişim sorununu ameliyathanede en az karşılaşılan sorunlar arasında belirtmelerine karşın, hekim ve hemşirelerin iletișimde güçlük yaratacak birçok etkenle karşılaştıkları ve bu nedenle iletişim sorunları yaşadıkları belirlendi. Görev ve sinırlılıkların bilinmemesi, tanınmama, motivasyon düşüklüğü, hekimlerin amir gibi davranması, yeterli sayıda tıbbi malzemenin ve personelin bulunmaması bu etkenler arasında yer aldı. Literatürde sağlık bakım disiplinlerinin, birbirine bağlı bir birim olmaktan ziyade ayrı birim olarak uygulama yapmaları, ekiplerdeki mevcut hiyerarşik ve statü farklılıkları, ekip üyelerinin bilgi paylaşma düzeylerini ve birbirleriyle etkileşim düzeyini etkilemektedir. ${ }^{16}$ Ameliyathanelerde de, özellikle ameliyat öncesi hazırlıklar sırasında, zaman baskısı, iş yükü ve rekabetçi iş akışı disiplinler arası iletişim firsatlarını sınırlamaktadır. ${ }^{16,23} \mathrm{Bu}$ açılardan bakıldığında çalışma bulgusu literatürle paralellik göstermektedir.

Sağlık çalışanlarında öfkeye neden olan durumlar çok çeşitli olabilmektedir. Çalışmada ameliyat sırasında kendilerini en fazla öfkelendiren durumu hemşirelerin \%69,2'si 
steril saha dışındaki ameliyathane personelinin yetersizliği, hekimlerin \%50'si ise cerrahi el aletlerinin kalitesizliği olarak belirtti. Ameliyat sırasında hekimlerin öfkeli davranışlarına maruz kalma ve çok fazla olumsuz etkilenme oranı hemşirelerde \%38,5 olurken, hemşirelerin öfkeli davranışlarına hekimlerin maruz kalmadıkları saptand1. Literatürde hekim ve hemşireler arasındaki etkin olmayan kişiler arası etkileşimler; küfürlü konuşma, bağırma/sesini yükseltme, saygısızlık, aşağılama gibi davranışlar yıkıcı davranış olarak tanımlanmaktadır. ${ }^{24}$ İnce'nin ${ }^{24}$ çalışmasında yoğun bakım ve ameliyathane hemşirelerinin yıkıcı hekim davranışlarını daha fazla deneyimledikleri; Koraş ve arkadaşlarının çalışmasında da benzer olarak ameliyathanede çalışan hemşirelerin cerrahların yıkıcı davranışlarına yüksek oranda maruz kaldıkları ve olumsuz etkilendikleri belirlenmiştir. ${ }^{11}$ Çalışmamızda bu oranın düşük olması ve katılımcıların \%60,7'sinin ekiple iletişimlerini olumlu değerlendirmeleri ekip arasındaki iletişimin iyi olduğunu göstermektedir. Çalışma yapılan kurumda ameliyathanede çalışan hekim ve hemşirelerin uzun süre beraber çalışmaları, birbirlerini daha iyi tanımaları etkili iletişim yaklaşımlarını olumlu yönde etkilemiş olabilir. Öfke ile ilgili yapılan çalışmalarda öfkenin yaşanmaması değil, öfkenin nasıl ifade edildiğinin önemi üzerinde durulmaktadır. İfade tarzı olarak öfkenin kontrol altına alınması ve dolaylı olmadan asertif bir şekilde ifadesinin uygun bir yol olduğu belirtilmektedir. ${ }^{18,19,25,26}$ Çalışmada tüm grubun puan ortalamaları içe yönelik öfke için 19,1 $\pm 3,2$, dişa yönelik öfke için $13,6 \pm 2,9$ ve öfke kontrolü için $23,9 \pm 4,1$ olarak belirlendi. Hekim ve hemșireler arasında öfke ifade tarzları açısından anlamlı bir fark saptanmadı. Elde edilen bu puanlara göre öfkenin içe atılmasının orta seviyede ancak öfkenin dışsallaştırılma puanından yüksek olduğu; genel olarak hekim ve hemşirelerin öfkelerini kontrol edebildikleri söylenebilir. Kontrol edilmiş öfke puan ortalamalarının yüksek olmasının olumlu bir özellik olduğu ve kontrol altına alınamayan öfkenin çeşitli iletişism sorunlarına yol açtığ düşünüldüğünde ${ }^{27} ; \quad$ bu bulgunun çalışmaya katılan hekim ve hemşirelerin iletişim sorunlarını ameliyathanede en az karşılan sorunlar arasında belirtmeleri ile örtüştüğü söylenebilir. Literatürde ameliyathane ekibinde hekim ve hemşirelerin öfke ifadelerinin birlikte değerlendirildiği çalışmaya rastlanmamıştır. Ancak hemşirelerin diğer bazı kliniklerde öfke ifadelerini araştıran çalışmalar mevcuttur. ${ }^{18,19,25-}$ $27 \mathrm{Bu}$ çalışmalarda da öfke ifade tarzları değerlendirilmiş ve hemşirelerin öfke kontrol puan ortalamaları çalışma bulgumuzla benzerdir. Çalışma bulgusu ve diğer bulgular birlikte değerlendirildiğinde profesyonel olmanın bir gereği olan öfke duygusunun kontrol altına alınmasının ekip içi iletişim sorunlarını azaltabildiği söylenebilir.

Çalışmada hemşirelerin sürekli öfke puan ortalamas1 $(18,5 \pm 5,1)$ hekimlerin puan 
ortalamasından $(16,1 \pm 3,4)$ yüksekti ancak bu yükseklik istatistiksel olarak anlamlı bulunmadı. Çalışma kapsamına alınan hekim ve hemşirelerin sürekli öfkelerinin orta düzeyde olduğu düşünülmektedir. Ameliyat sırasında yetersizlik yaşayan bir ekip üyesi olduğunda katılımcılardan her iki grupta da yüksek oranda "normal ses tonu ile uyarırım” cevabının alınmış olması ve iletişim güçlüğü yaşandığında da sorunu ortadan kaldırmak için katılımcıların çoğunluğunun çözüm yolu arama ve karşılıklı konuşma davranışını seçtiğinin belirlenmiş olması bu düşünceyi destekler niteliktedir. Ayrıca yıkıcı davranışlara maruz kalmanın sık olduğu düşünülen ameliyathanelerde çalışanların öfke ifade biçimlerinin değerlendirilmesi açısından bu çalışmanın literatüre katkı sağlayacağı düşünülmektedir.

Sonuç olarak; hekim ve hemşirelerin iletişim sorunlarına neden olan faktörleri farklı değerlendirdikleri, ekip içi iletişimi etkileyebilecek çeşitli sorunlarla karşılaştıkları, iletişim sorunlarına çözüm odaklı yaklaştıkları ve öfkelerini kontrol edebildikleri belirlenmiştir. $\mathrm{Bu}$ doğrultuda ameliyathanede görev yapan hekim ve hemşireler için ekip çalışması ve iletişimin önemi ile öfke kontrol yöntemlerini içeren hizmet içi eğitim (oryantasyon, seminer vb.) programlarının planlanması önerilebilir.

\section{KAYNAKLAR}

1. Özsoy S, Bayık A, Uysal A, Ergül Ş, Özer M. Sağlık çalışanlarının sağlık hizmetlerinde ekip kavramına ilişkin görüşlerini incelenmesi. Sağlı ve Toplum Dergisi. 2003;13(4):24-31.

2. Ulusoy H, Tokgöz DM. Hekim ve hemşirelerin ekip çalışmasına ilişkin görüşleri. Pamukkale Tip Dergisi, 2009;2(2):55-61.

3. Lafçı D, Pehlivan S, Demiray G. Cerrahi kliniklerinde çalıșan hekim ve hemşirelerin ekip çalışmasına ilişkin görüşleri. Sağlık ve Hemşirelik Yönetimi Dergisi. 2016;2(3):5564.

4. Önler E, Kocadaş S B, Kılıç M A. Ekip çalışmasında iletişimin önemi. Euras J Health Sci. 2016;1(1):12-16.

5. Weaver S J, Rosen M A, DiazGranados D, et al. Does teamwork improve performance in the operating room? A multilevel evaluation. The Joint Commission Journal On Quality And Patient Safety. 2010;36(3):133-142.

6. Awad S S, Fagan S P, Bellows C, et al. Bridging the communication gap in the operating room with medical team training. The American Journal of Surgery. 2005;190(5):770-774.

7. Lingard L, Espin S, Whyte S, et al. Communication failures in the operating room: an observational classification of recurrent types and effects. Qual Saf Health Care. 2004;13(5):330-334. 
8. Garrett J H. Effective perioperative communication to enhance patient care. AORN Journal. 2016;104(2):111-17.

9. O'leary K J, Ritter C D, Wheeler H, et al. Teamwork on inpatient medical units: assessing attitudes and barriers. Qual Saf Health Care. 2010;19(2):117-121.

10. Halverson A L, Casey J T, Andersson J, et al. Communication failure in the operating room. Surgery. 2011;149(3):305-10.

11. Koraş K, Öcalan D, Solak O. Cerrahi hekimlerin ameliyathanedeki gergin davranışlarının hemşireler üzerindeki etkileri. Gümüşhane Üniversitesi Sağlık Bilimleri Dergisi. 2015;4(4): 504.

12. Baker D P, Day R, Salas E. Teamwork as an essential component in high reliability organizations. Health Res Serv 2006;41(4):1576-1598.

13. Hergül F K, Özbayır T, Gök F. Ameliyathanede hasta güvenliği: Sistematik derleme. Pamukkale Tip Dergisi. 2016;9(1):87-89.

14. Weldon S M, Korkiakangas T, Bezemer J, Kneebone R. Communication in the operating theatre. Br J Surg. 2013;100(13):1677-1688.

15. Parish A, Kramer C, Foster-Hunt T, et al. Communication and team situation awareness in the OR: Implications for augmentative information display. J Biomed Inform. 2011; 44(3): 477-485

16. Gillespie B, Chaboyer W, Longbottom P, Wallis M. The impact of organisational and individual factors on team communication in surgery: A qualitative study. Int J Nurs Stud. 2010;47(6):732-741.

17. Yavuz Van Gıersbergen M. Etkili İletişim. İç: Yavuz Van Giersbergen M., Kaymakçı S. ed. Ameliyathane Hemşireliği. İzmir; Meta Basım ve Matbaacılık Hizmetleri; 2015:9-18.

18. Baran M, Okanlı A. Hemşirelerde öfke düzeyinin iş doyumuna etkisi. Anadolu Hemşirelik ve Sağlık Bilimleri Dergisi. 2015;18(1):43-49.

19. Kocatepe V, Uğur E, Karabacak Ü. Yoğun bakım ve palyatif bakım ünitelerinde çalışan hemşirelerin sürekli öfke ve öfke ifade tarzları ile bakım davranışları arasındaki ilişki. F.N. Hem Derg, 2017;25(1):13-20.

20. Manojlovich, M. Nurse / physician communication through a sensemaking lens: shifting the paradigm to improve patient safety. Medical care. 2010;48(11):941-946.

21. Özer K. Sürekli öfke (SL-Öfke) ve öfke tarzı (Öfke-Tarz) ölçekleri ön çalışması. Türk Psikoloji Dergisi. 1994;31:26-35.

22. Savaşır I, Hisli Şahin N. Bilişsel-Davranışçı Terapilerde Değerlendirme. Ankara; Türk Psikologlar Derneği Yayınları; 1997.

23. Clayton J, Isaacs A $\mathrm{N}$, Ellender I. Perioperative nurses' experiences of communication in a multicultural operating theatre: A qualitative study. Int J Nurs Stud. 2016;54(-):7-15.

24. İnce S. Hekim davranıșlarının hemșirelerin stresle başetme durumları üzerine etkisi. 
Hemşirelikte Araştırma Geliştirme Dergisi. durumları arasındaki ilişki. Turkiye Klinikleri 2014;16(2):41-53. J Nurs Sci. 2009;1(2):65-70.

25. Kaya N, Solmaz Ş. Bir üniversite 27. Han A, Won J, Kim O, Lee S E. Anger hastanesinin kulak burun boğaz kliniğinde expression types and interpersonal problems çalışan hemşirelerin öfke ve öfke ifadesi. in nurses. Asian Nurs Res. 2015;9(2):146Turkiye Klinikleri J Nurs Sci. 2009;1(2):56151.

64.

26. Bayri F, Kelleci M. Hemşirelerin sürekli öfke ve öfke ifade tarzları ile genel sağlık 
Tablo 1. Katılımcıların Demografik ve Mesleki Özelliklerinin Dağılımı

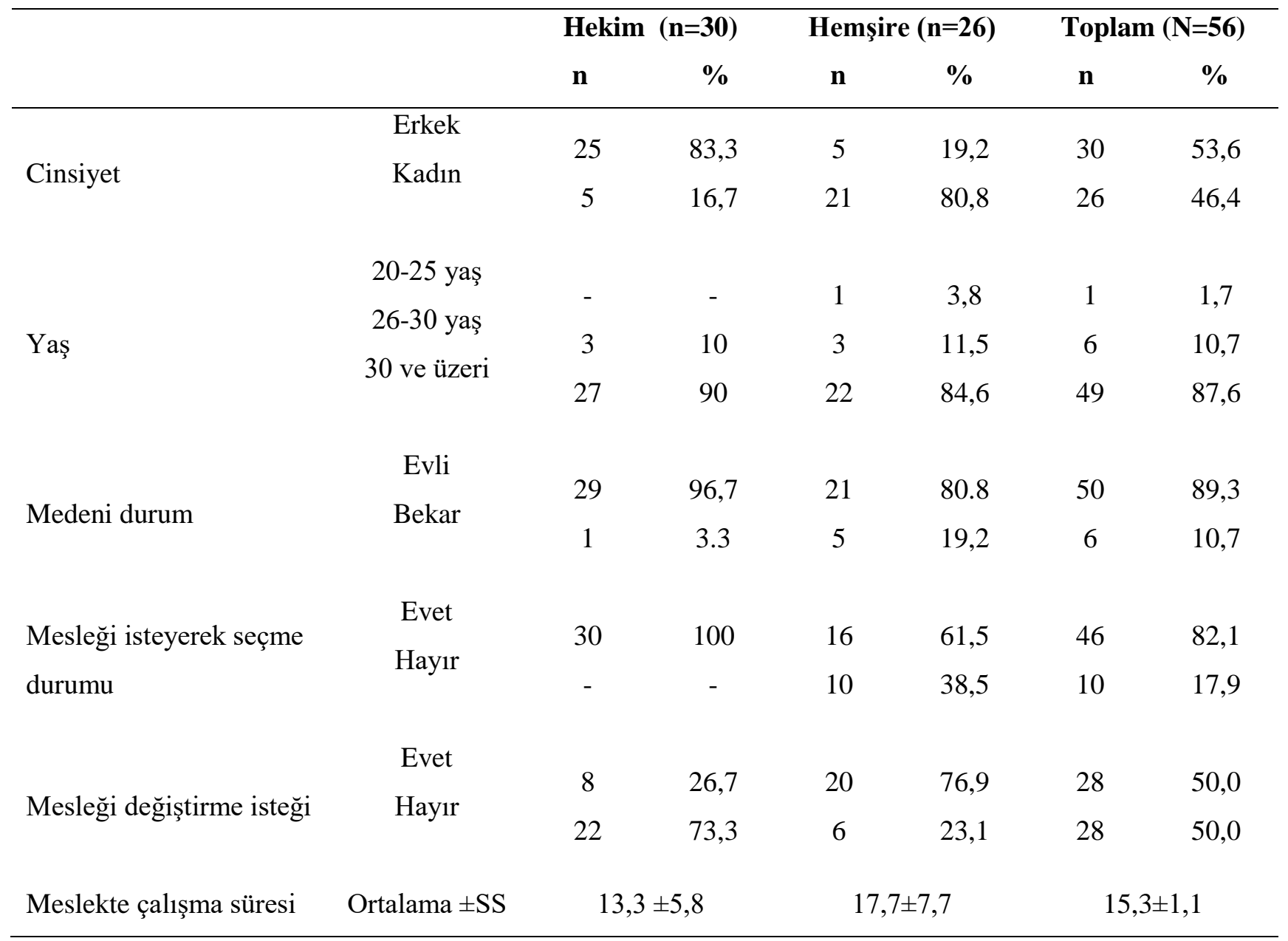


Tablo 2. Katılımcıların İletişime Ait Görüş ve Özelliklerinin Dağılımı

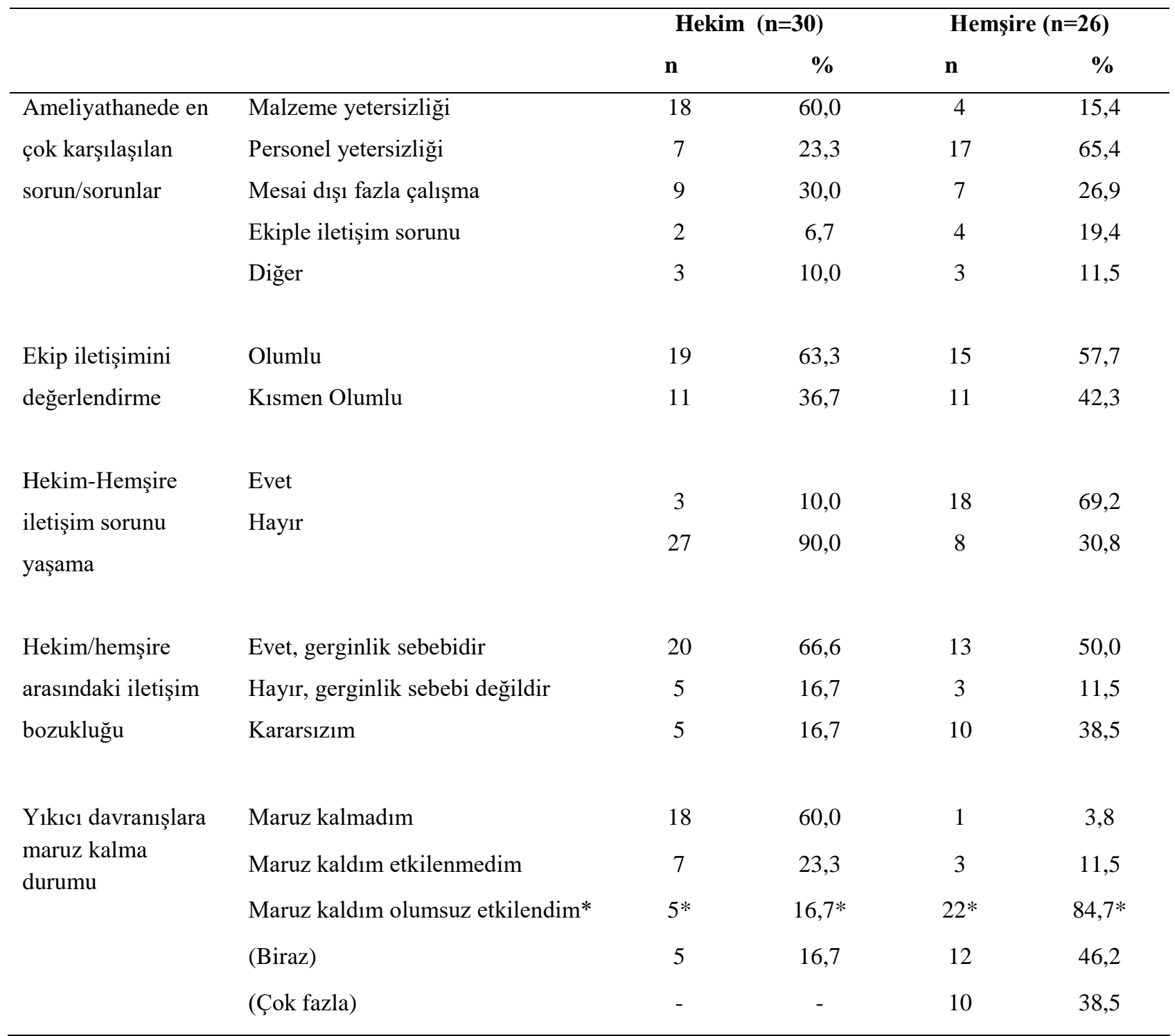

*Biraz olumsuz etkilenme ve çok fazla olumsuz etkilenme oranlarının toplam sayı ve yüzdeliğidir. 
Tablo 3. Hekim ve Hemşirelerin Sürekli Öfke ve Öfke İfade Tarzı Ölçeği (SÖ-ÖTÖ) Puan Ortalamalarının Dağılımı

\begin{tabular}{lcccc}
\hline \multicolumn{1}{c}{ SÖ-ÖTÖ } & $\begin{array}{c}\text { Ölçekten alınabilecek } \\
\text { puanlar } \\
\text { (Min-Max) }\end{array}$ & $\begin{array}{c}\text { Hekim } \\
\text { Ortalama-SS }\end{array}$ & $\begin{array}{c}\text { Hemşire } \\
\text { Ortalama-SS }\end{array}$ & $\begin{array}{c}\text { Toplam } \\
\text { Ortalama-SS }\end{array}$ \\
\hline Sürekli Öfke & $10-40$ & $16,1 \pm 3,4$ & $18,5 \pm 5,0$ & $17,2 \pm 4,3$ \\
İçe Yönelik Öfke & $8-32$ & $15,9 \pm 3,6$ & $16,5 \pm 2,7$ & $19,1 \pm 3,2$ \\
D1şa Yönelik Öfke & $8-32$ & $13,2 \pm 3,1$ & $14,1 \pm 2,8$ & $13,6 \pm 2,9$ \\
Öfke Kontrol & $8-32$ & $24,7 \pm 3,4$ & $23,0 \pm 4,6$ & $23,9 \pm 4,1$ \\
\hline
\end{tabular}

Tablo 4. Katılımcıların Sürekli Öfke ve Öfke İfade Tarzı Ölçeği (SÖ-ÖTÖ) Puan Ortalamalarının Cinsiyet ve Mesleğe göre Karşılaştırılması

\begin{tabular}{|c|c|c|c|c|}
\hline \multirow[b]{2}{*}{ SÖ-ÖTÖ } & \multicolumn{3}{|c|}{ Sira Ortalamas1 } & \multirow[b]{2}{*}{$\mathrm{p}$} \\
\hline & & (Mean Rank) & $\mathrm{Z}^{*}$ & \\
\hline \multirow{3}{*}{ Sürekli Öfke } & Hekim & 25,0 & $-1,733$ & 0,083 \\
\hline & Hemşire & 32,5 & & \\
\hline & Kadın & 25,7 & $-1,172$ & 0,241 \\
\hline \multirow{5}{*}{ İçe Yönelik Öfke } & Erkek & 30,8 & & \\
\hline & Hekim & 26,8 & $-0,800$ & 0,424 \\
\hline & Hemşire & 30,3 & & \\
\hline & Kadın & 27,2 & $-0,544$ & 0,586 \\
\hline & Erkek & 29,6 & & \\
\hline \multirow{4}{*}{ Dışa Yönelik Öfke } & Hekim & 25,9 & $-1,278$ & 0,201 \\
\hline & Hemşire & 31,4 & & \\
\hline & Kadın & 27,2 & $-0,523$ & 0,601 \\
\hline & Erkek & 29,5 & & \\
\hline \multirow{4}{*}{ Öfke Kontrol } & Hekim & 31,2 & $-1,370$ & 0,171 \\
\hline & Hemşire & 25,3 & & \\
\hline & Kadın & 27,3 & $-0,495$ & 0,620 \\
\hline & Erkek & 29,5 & & \\
\hline
\end{tabular}

*Mann-Whitney $U$ 
Tablo 5. Katılımcıların Mesleki çalışma süresi ile SÖ-ÖTÖ arasındaki ilişki

\begin{tabular}{lccccc}
\hline & & Sürekli Öfke & İçe Yönelik Öfke & Dişa Yönelik Öfke & Öfke Kontrol \\
\hline $\begin{array}{l}\text { Meslekte } \\
\text { süresilışma }\end{array}$ & $\mathrm{r}^{*}$ & 0,58 & $-0,14$ & 0.01 & -0.06 \\
& $\mathrm{p}$ & 0,670 & 0,299 & 0,921 & 0,633
\end{tabular}

*Spearmen korelasyon analizi 